\title{
GROWTH INHIBITION OF ASPERGILLUS OCHRACEUS ZMPBF 318 AND PENICILLIUM EXPANSUM ZMPBF 565 BY FOUR ESSENTIAL OILS
}

\author{
Domagoj ČVEK, Ksenija MARKOV, Jadranka FRECE, Tibela LANDEKA DRAGIČEVIĆ, \\ Matea MAJICA, and Frane DELA ̌́
}

University of Zagreb, Faculty of Food Technology and Biotechnology, Zagreb, Croatia

Received in October 2009

Accepted in February 2010

\begin{abstract}
Fungi produce a large variety of extracellular proteins, organic acids, and other metabolites and can adapt to several environmental conditions. Mycotoxin-producing moulds of the genera Aspergillus and Penicillium are common food contaminants. One of the natural ways to protect food from mould contamination is to use essential oils. In this study, we evaluated the effect of essential oils of cinnamon, lavender, rosemary, and sage at $1 \%(\mathrm{v} / \mathrm{v})$ concentration in yeast media inoculated with spores (final concentration $10^{6} \mathrm{~mL}^{-1}$ media) of Aspergillus ochraceus ZMPBF 318 and Penicillium expansum ZMPBF 565, alone or in combination, on fungal biomass. Cinnamon showed the best inhibitory effect (100\%). Lavender oil best inhibited the growth of Aspergillus ochraceus (nearly $100 \%$ ), and was less successful with Penicillium expansum (having dropped to $57 \%$ on day 28). With cultivation time the inhibitory effect of sage and rosemary oil grew for Aspergillus ochraceus and dropped for Penicillium expansum.

These results suggest that fungi can be controlled with essential oils, especially with cinnamon oil.
\end{abstract}

KEY WORDS: inhibitory effect, mixed culture, pure culture, spore suspensions, Yeast media

From the dawn of times people have sought ways to preserve food. The most common way is heating, freezing, drying, salting, and use of preservatives. Antimicrobial plant products have been gaining particular popularity, mostly because of the increasing public concern about the potential effect of synthetic additives on health $(1,2)$.

In pharmaceutical, food, and cosmetics industries, essential oils and plant extracts and their have seen a widespread application $(3,4)$. Many essential oils and their ingredients possess antibacterial, antifungal, and antiviral properties (5-13). These include cassia, cinnamon, clove, garlic, sage, oregano, pimento, thyme, rosemary, scutellaria, and other (14). The most effective among these are eugenol in clove, allicin in garlic, and cinnamic aldehyde and eugenol in cinnamon (15). Combinations of two or more essential oils may also have a beneficial role in preserving food (16-18). A combination of cinnamon and clove oils suppressed the growth of major spoilage microorganisms of intermediate moisture foods (1921). Fungi are a common cause of food spoilage. Among the leading food and feed contaminant are some Aspergillus species (22-24). Aspergillus flavus and Aspergillus parasiticus produce aflatoxins in food and feedstuffs (25). These mycotoxins can be potent hepatocarcinogens in animals and humans. The presence of toxigenic fungi and mycotoxins in food is hazardous to human and animal health and it is very important to find a way to prevent food contamination with fungi (18).

The use of essential oils in the preservation of food gained considerable interest because essential oils slow down fungal growth and lower mycotoxin production 
(13). So far, several studies have investigated the antimicrobial activity of some essential oil components against foodborne pathogens, including mycotoxin-producing fungi $(6-12,15,17)$.

The aim of this study was to investigate the effect of four essential oils (cinnamon, sage, lavender, and rosemary) on the growth of Aspergillus ochraceus ZMPBF 318 and Penicillium expansum ZMPBF 565 grown in pure and mixed cultures and to determine which of these essential oils has the best properties as a potential antifungal agent.

\section{MATERIALS AND METHODS}

\section{Microorganisms}

Aspergillus ochraceus ZMPBF 318 (isolated from a home-made sausage) and Penicillium expansum ZMPBF 565 (isolated from an apple), potential producers of ochratoxin A and patulin, respectively, were obtained from the Collection of Microorganisms of the Laboratory of General Microbiology and Food Microbiology, Zagreb University Faculty of Food Technology and Biotechnology, Zagreb, Croatia. They were stored on potato dextrose agar (PDA) slants (Biolife, Italy) at $4{ }^{\circ} \mathrm{C}$.

\section{Inoculum}

For 7 days before inoculation, the investigated moulds were grown on PDA slants at the temperature of $28^{\circ} \mathrm{C}$. Their conidia were harvested by adding $2 \times 5 \mathrm{~mL}$ of sterile $\left(10^{6} \mathrm{cfu} \mathrm{mL}^{-1}\right)$ solution of Triton X-100 (Sigma) in laminar flow. Suspended spores of both moulds were counted in a Thoma chamber and then adjusted the number of conidia to approximately $10^{6} \mathrm{~mL}^{-1}$.

\section{Essential oils}

The selection of cinnamon, sage, lavender, and rosemary oil was based on their reported antimicrobial efficiency. These oils were obtained from a local pharmacy. The essential oils were dissolved in $96 \%$ ethanol (Kemika, Croatia) (1:10, v/v).

\section{Yeast media}

Yeast media (yeast extract $2 \%$, sucrose $20 \%$, distilled water $1 \mathrm{~L}$ ) was used as a liquid substrate. Fifty millilitres of the media was distributed into $250 \mathrm{~mL}$
Erlenmeyer flasks and autoclaved at $121{ }^{\circ} \mathrm{C}$ for 20 min. Forty-eight flasks were then inoculated with Aspergillus ochraceus and/or Penicillium expansum in $1 \mathrm{~mL}$ spore suspensions. Five millilitres of each essential oil, at the concentration of $10 \%(\mathrm{v} / \mathrm{v})$, were pipetted into test flasks. Control flasks and duplicate test flasks were incubated as a stationary culture at $27^{\circ} \mathrm{C}$ for $7,14,21$, and 28 days.

\section{Determination of mould biomass}

Control flasks and duplicate test flasks (containing one of the tested essential oils) were analysed for mould biomass every 7 days of cultivation. Mycelium was separated from the liquid medium by filtration through pre-weighed Whatman No. 1 filter paper. The filter paper and the mycelia were dried in a hotair oven at $105{ }^{\circ} \mathrm{C}$ for 24 hours. The mass of mycelia was obtained by deducting the pre-weighed filter paper mass from the mass of the filter paper with dried mycelia.

\section{Statistical analysis}

Experiments were repeated twice and the analyses were done at least in duplicate. Data were subjected to analysis of variance (ANOVA) using the general linear model to determine treatment effects. When treatment was found to be significant $(\mathrm{P}<0.05)$, differences between sample means were identified using the least significance difference method.

\section{RESULTS}

In the preliminary experiment, we determined the biomass of untreated Aspergillus ochraceus ZMPBF 318 and Penicillium expansum ZMPBF 565, grown as pure and mixed stationary cultures in yeast media at $27{ }^{\circ} \mathrm{C}$ for 28 days. Both moulds and their mixture had the greatest biomass on day 21 after inoculation (Table 1).

Table 2 and Figures 1-3 show the effect of essential oils on mould growth. Cinnamon oil was the most effective inhibitor; it completely inhibited the growth of both moulds and their mixture for 21 days. Only on day 28 of cultivation did this drop from $100 \%$ to $98.80 \%$ in Aspergillus ochraceus, to $98.54 \%$ in Penicillium expansum, and to $97.54 \%$ in the mixed culture.

Lavender completely inhibited the growth of Aspergillus ochraceus for 14 days. There after 


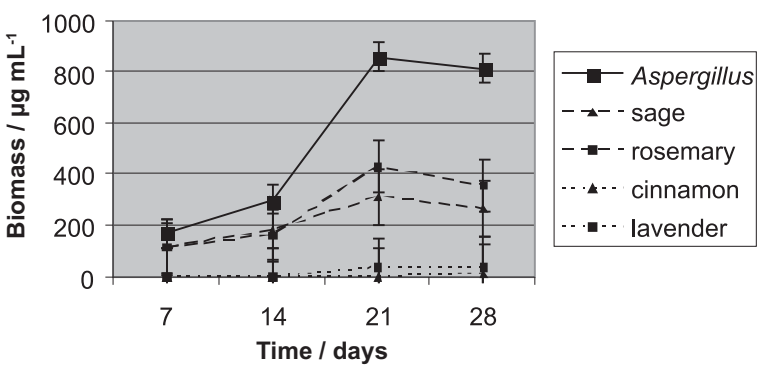

Figure 1 Inhibitory effect of essential oils on the growth of Aspergillus ochraceus ZMPBF 318. Error bars represent standard deviations of the mean values

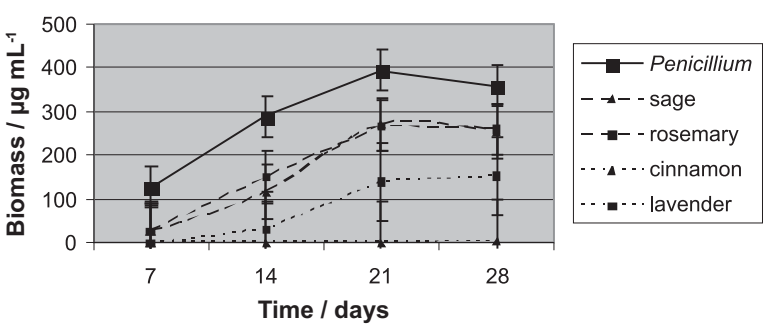

Figure 2 Inhibitory effect of essential oils on the growth of Penicillium expansum ZMPBF 565. Error bars represent standard deviations of the mean values

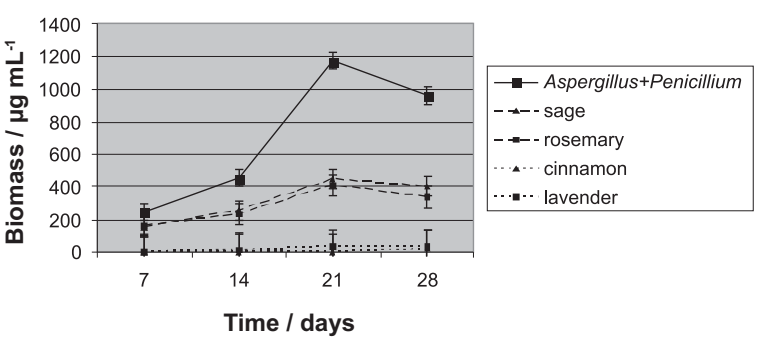

Figure 3 Inhibitory effect of essential oils on the growth of Aspergillus ochraceus ZMPBF 318 and Penicillium expansum ZMPBF 565 as a mixed culture. Error bars represent standard deviations of the mean values

the inhibition dropped about $5 \%$. Inhibition of Penicillium expansum was less successful. On day 28 of cultivation, it dropped to $57.26 \%$. In the mixed culture lavender inhibition was $100 \%$ on day 7 and by day 28 it dropped to $95.80 \%$.

On day 7 , sage oil was more successful in inhibiting the growth of Penicillium expansum (78.71\%) than of Aspergillus ochraceus (34.33\%). However, the inhibitory effect on Aspergillus ochraceus and the mixed culture increased steadily in the weeks that followed, while it decreased for Penicillium expansum. The same behaviour was observed for the rosemary oil.

\section{DISCUSSION AND CONCLUSION}

Microbiology has now turned its spotlights on mixed mould cultures because mixed cultures are often biochemically more active than pure cultures and definitely much more common outside the laboratory. Monitoring biomass is important because the amount of biomass in the substrate affects the synthesis of metabolic products.

This study has shown significant inhibitory effect of the essential oils on the biomass Aspergillus ochraceus ZMPBF 318 and Penicillium expansum ZMPBF 565 in liquid yeast media. Cinnamon was the most effective, followed by lavender, sage, and rosemary.

These results are consistent with studies of the effect of cinnamon oil on the growth of Aspergillus ochraceus $(6,7)$. High concentrations of cinnamon seem to inhibit the development of asexual spores and cause significant morphological changes in the mycelium of the Aspergillus genera (6). Tzorzakis (8) has shown that cinnamon oil in the concentration of $2 \%(\mathrm{v} / \mathrm{v})$ completely inhibits the growth of the genera Aspergillus and Penicillium. Its also seem to have fungicidal properties (8). This gives cinnamon oil a great advantage over other essential oils for use in packaging and storing fruit products.

Essential oils can consist of more than 60 components, but their contribution is uneven, as the major component usually accounts for $85 \%$ of the content (12). Many major components have antimicrobial properties. Minor components may play a critical part in antimicrobial activity, possibly through synergy with the major and other components (13). The antimicrobial activity of essential oils can not be attributed to a single mechanism, but to the existence of several targets in the cell. This is probably due to the large number of different groups of chemical compounds present in essential oils (21).

The inhibitory effect of sage and rosemary oil differed between Penicillium expansum and Aspergillus ochraceus. With P. expansum it peaked on day 7 and steadily dropped toward day 28., while with $A$. ochraceus the inhibition steadily increased through day 28. This is probably because Aspergillus is more aggressive than Penicillium and it takes longer for sage and rosemary oil to achieve their full $d$ inhibitory effect. Further research might shed some more light on this effect.

Future studies might also answer why our mixed culture did not show greater resistance to essential 
Table 1 Biomass of pure and mixed cultures

\begin{tabular}{|c|c|c|c|}
\hline $\begin{array}{l}\text { Culture } \\
\text { day }\end{array}$ & 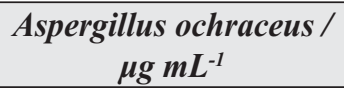 & $\begin{array}{c}\text { Penicillium expansum / } \\
\mu \mathrm{g} m L^{-1}\end{array}$ & $\begin{array}{c}\text { Aspergillus ochraceus and } \\
\text { Penicillium expansum / } \mu g \mathrm{~mL}^{-1}\end{array}$ \\
\hline 7 & $174.2 \pm 0.14$ & $126.8 \pm 0.22$ & $251.2 \pm 0.26$ \\
\hline 14 & $300 \pm 0.29$ & $289.4 \pm 0.53$ & $455.2 \pm 0.31$ \\
\hline 21 & $859.8 \pm 0.17$ & $393.4 \pm 0.15$ & $1173 \pm 0.42$ \\
\hline 28 & $813 \pm 0.23$ & $357 \pm 0.11$ & $957.2 \pm 0.74$ \\
\hline
\end{tabular}

Table 2 Inhibitory effect (\%) of essential oils on mould growth

\begin{tabular}{lccccc}
\hline & \multicolumn{5}{c}{ Inhibition / \% } \\
\hline Moulds & Culture day & Cinnamon & Lavender & Rosemary & Sage \\
\cline { 2 - 6 } Aspergillus ochraceus & 7 & $100 \pm 0.23$ & $100 \pm 0.11$ & $33.53 \pm 0.15$ & $34.33 \pm 0.17$ \\
\cline { 2 - 6 } & 14 & $100 \pm 0.17$ & $100 \pm 0.15$ & $46.20 \pm 0.12$ & $39.20 \pm 0.07$ \\
\cline { 2 - 6 } & 21 & $100 \pm 0.15$ & $95.81 \pm 0.21$ & $49.78 \pm 0.21$ & $63.78 \pm 0.20$ \\
\hline \multirow{nyyyyy}{*}{ Penicillium expansum } & 28 & $98.80 \pm 0.32$ & $94.81 \pm 0.17$ & $56.16 \pm 0.19$ & $67.23 \pm 0.18$ \\
\cline { 2 - 6 } & 1 & $100 \pm 0.11$ & $100 \pm 0.19$ & $79.18 \pm 0.17$ & $78.71 \pm 0.22$ \\
\hline \multirow{nyyyyy}{*}{ Aspergillus ochraceus and } & 21 & $100 \pm 0.14$ & $89.91 \pm 0.14$ & $48.10 \pm 0.14$ & $39.67 \pm 0.14$ \\
\cline { 2 - 6 } Penicillium expansum & 28 & $98.54 \pm 0.07$ & $57.26 \pm 0.16$ & $27.84 \pm 0.24$ & $28.80 \pm 0.23$ \\
\cline { 2 - 6 } & 14 & $100 \pm 0.11$ & $100 \pm 0.22$ & $35.43 \pm 0.22$ & $37.74 \pm 0.21$ \\
\cline { 2 - 6 } & 21 & $100 \pm 0.22$ & $97.06 \pm 0.21$ & $48.51 \pm 0.16$ & $43.63 \pm 0.11$ \\
\hline
\end{tabular}

oils than the pure cultures, as mixed cultures are usually more aggressive than pure. Recent studies on eukaryotic cells have shown that the ingredients of essential oils can have pro-oxidative effect on the cell membrane and organelles such as mitochondria. Depending on oil composition and concentration, they can also have cytotoxic effects that may be useful in preservation of agricultural and marine products (17).

Our study has clearly confirmed that essential oils should find practical application as inhibitors mould growth, especially because they are generally regarded as safe. They could be added to stored grain to protect it from fungal infection. Essential oils have a lot of advantages. One is their bioactivity in the vapour phase, a characteristic which makes them attractive as fumigants.

Future research in this field should answer how individual essential oil components affect the growth of microorganisms to maximise their efficiency.

\section{REFERENCES}

1. Reische DW, Lillard DA, Eintenmiller RR. Antioxidants in food lipids. In: Ahoh CC, Min DB, editors. Chemistry, nutrition and biotechnology. New York (NY): Marcel Dekker; 1998. p. 423-48.

2. Essawi T, Srour M. Screening of some Palestinian medicinal plants for antibacterial activity. J Ethnopharmacol 2000;70:343-9.

3. Stammatiy A, Moezelaar R, Alakomi H-L, von Wright A. Toxicity of selected plant volatiles in microbial and mammalian short-term assay. Food Chem 1999;37:813-23.

4. Gutierrez J, Barry-Ryan C, Bourke P. The antimicrobial efficacy of plant essential oil combinations and interactions with food ingredients. Int Food Microbiol 2008;124:91-7.

5. Oplachenova G, Obreshkova D. Comparative studies on the activity of basil-an essential oil from Ocimum basilicum L. against multidrug- resistant clinical isolates of the genera Staphylococcus, Enterococcus, and Pseudomonas by using different test methods. J Microbiol Methods 2003;54:10510.

6. Carmo ES, de Oliveira Lima E, de Souza EL, de Sousa FB. Effect of cinnamomum zeylanicum blume essential oil on the growth and morphogenesis of some potentially pathogenic Aspergillus species. Braz J Microbiol 2008;39:198-202.

7. Soliman KM, Badea RI. Effect of oil exstracted from some medicinal plants on different mycotoxigenic fungi. Food Chem Toxicol 2002;40:1669-75.

8. Tzortzakis, NG. Impact of cinnamon oil-enrichment on microbial spoilage on fresh produce. Innov Food Sci Emerg Technol 2009;10:97-102.

9. Chatterjee D. Inhibition of fungal growth and infection in maize grains by spice oils. Lett Appl Microbiol 1990;11:14851.

10. Tatsadjieu NL, Jazet Dongmo PM, Ngassoum MB, Etoa FX, Mbofung, CMF. Investigations on the essential oil of Lippia 
rugosa from Cameroon for its potential use as antifungal agent against Aspergillus flavus Link ex. Fries. Food Control 2009;20:161-6.

11. Tatsadjieu NL, Ngassoum MB, Nukenine EN, Mbawala A, Yaouba A. Antifungal and anti-insect activities of three essential oils on A. flavus link and S. zea mays Motsch. Natural Product Communications 2007;12:1291-4.

12. Senatore F. Influence of harvesting time on yield and composition of the essential oil of a Thyme (Thymus pulegioides L.) growing wild in Campania (Southern Italy). J Agric Food Chem 1996;44:1327-32.

13. Burt S. Essential oils: their antimicrobial properties and potential applications in foods - a review. Int J Food Microbiol 2004;94:223-53.

14. Kong BH, Wang JZ, Xiong YL. Antimicrobial activity of several herb and spice extracts in culture medium and in vacuum-packaged pork. J Food Protect 2007;70:641-7.

15. Bullerman LB, Lieu FY, Seier SA. Inhibition of growth and aflatoxin production by cinnamon and clove oils, cinnamic aldehyde and eugenol. J Food Sci 1977;42:1107-9.

16. Martinez-Romero D, Guillen F, Valverde JM, Bailen G, Zapata P, Serrano M, Castillo S, Valero D. Influence of carvacrol on survival of Botrytis cinerea inoculated in table grapes. Int J Food Microbiol 2007;115:144-8.

17. Bakkali F, Averbeck S, Averbeck D, Idaomar M. Biological effects of essential oil: a review. Food Chem Toxicol 2008;46:446-75

18. Tripati P, Dubey NK. Exploitation of natural products as an alternative strategy to control postharvest fungal rotting of fruit and vegetables. Postharvest Biol Technol 2004;32:23545 .
19. Matan N, Rimkeeree H, Mawson AJ, Chompreeda P, Haruthaithanasan V, Parker M. Antimicrobial activity of cinnamon and clove oils under modified atmosphere conditions. Int J Food Microbiol 2006;107:180-5.

20. Oussalah M, Caillet S, Saucier L, Lacroix M. Inhibitory effects of selected plant essential oils on the growth of four pathogenic bacteria: E. coli O157:H7, Salmonella Typhimurium, Staphylococcus aureus and Listeria monocytogenes. Food Control 2007;18:414-20.

21. Skandamis PN, Nychas G-JE. Development and evaluation of a model predicting to the survival of Escherichia coli O157H7 NCTC 12900 in homemade eggplant salad at various temperatures, $\mathrm{pHs}$ and oregano essential oils concentration. Appl Environ Microbiol 2000;66:1646-53.

22. Abarc ML, Bragulat MR, Castella G, Cabanes FJ. Mycoflora and aflatoxin producing strains in animal mixed feeds. J Food Protect 1994;57:256-8.

23. Coulibaly L, Gourene G, Agathos NS. Utilization of fungi for biotreatment of raw wastewaters. African J Biotechnol 2003;2:620-30.

24. Ramos AJ, Magan N, Sanchis V. Osmotic and matric potential effects on growth, sclerotia and partitioning of polyols and sugars in colonies and spores of Aspergillus ochraceus. Mycol Res 1999;103:141-7.

25. Guo BZ, Russin JS, Brown RL, Celveland TE, Widstrom NW. Resistance to aflatoxin contamination in corn as influenced by relative humidity and kernel germination. J Food Protect 1996;59:276-81. 


\section{Sažetak}

INHIBICIJA RASTA PLIJESNI ASPERGILLUS OCHRACEUS ZMPBF 318 I PENICILLIUM EXPANSUM ZMPBF 565 DJELOVANJEM ČETIRIJU ETERIČNIH ULJA

Plijesni su poznate po svojoj visokoj sposobnosti proizvodnje različitih izvanstaničnih proteina, organskih kiselina i drugih metabolita i po svojoj mogućnosti prilagodbe na nepovoljne okolišne uvjete, a primjenjuju se i u obradi otpadnih voda. Plijesni iz rodova Aspergillus i Penicillium česti su kontaminanti u hrani i posebno opasne jer tvore toksične metabolite mikotoksine. Eterična ulja mogu se primijeniti kao prirodna sredstva za zaštitu hrane od kontaminacije plijesnima. U radu su prikazani rezultati istraživanja utjecaja eteričnih ulja cimeta, lavande, ružmarina i kadulje na kontrolu rasta biomase plijesni Aspergillus ochraceus ZMPBF 318 i Penicillium expansum ZMPBF 565, u obliku čistih i miješanih kultura. Ulja su dodavana u koncentraciji od $1 \%(\mathrm{v} / \mathrm{v})$, a podloga (kvaščev ekstrakt) bila je nacijepljena suspenzijama spora plijesni $\left(10^{6} \mathrm{~mL}^{-1}\right.$ podloge). Eterično ulje cimeta pokazalo je najveći inhibitorni učinak (100 \%). Inhibitorni učinak eteričnog ulja lavande bio je veći na rast Aspergillusa ochraceusa (skoro $100 \%$ ) nego Penicilliuma expansuma $(57 \%)$. Eterična ulja kadulje i ružmarina pokazala su suprotne učinke. Inhibitorni učinak na Aspergillus ochraceus tijekom perioda uzgoja je rastao, a na Penicillium expansum opadao.

Rezultati pokazuju da se rast plijesni može kontrolirati primjenom eteričnih ulja, a posebno uljem cimeta. Također upućuju na ekonomsku vrijednost takvih tretmana.

KLJUČNE RIJEČI: čista kultura, inhibitorni učinak, kvaščev ekstrakt, mješovita kultura, suspenzija spora

\section{CORRESPONDING AUTHOR:}

\section{Domagoj Čvek}

University of Zagreb, Faculty of Food Technology and

Biotechnology

Pierottieva 6, 10000 Zagreb, Croatia

E-mail:dcvek@pbf.hr 